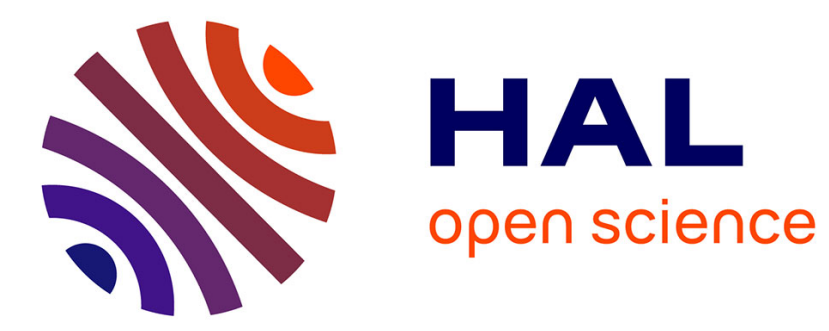

\title{
Low-temperature synthesis of $\alpha$-alumina nanosheets on microfibrous-structured Al-fibers for Pd-catalyzed CO oxidative coupling to dimethyl oxalate
}

Chunzheng Wang, Weisong Xu, Zhengxing Qin, Xinmei Liu, Svetlana Mintova

\section{- To cite this version:}

Chunzheng Wang, Weisong Xu, Zhengxing Qin, Xinmei Liu, Svetlana Mintova. Low-temperature synthesis of $\alpha$-alumina nanosheets on microfibrous-structured Al-fibers for Pd-catalyzed CO oxidative coupling to dimethyl oxalate. Catalysis Today, 2020, 354, pp.158-166. 10.1016/j.cattod.2019.03.005 . hal-02409902

\author{
HAL Id: hal-02409902 \\ https://hal.science/hal-02409902
}

Submitted on 27 Nov 2020

HAL is a multi-disciplinary open access archive for the deposit and dissemination of scientific research documents, whether they are published or not. The documents may come from teaching and research institutions in France or abroad, or from public or private research centers.
L'archive ouverte pluridisciplinaire $\mathbf{H A L}$, est destinée au dépôt et à la diffusion de documents scientifiques de niveau recherche, publiés ou non, émanant des établissements d'enseignement et de recherche français ou étrangers, des laboratoires publics ou privés. 


\section{Low-temperature synthesis of $\alpha$-alumina nanosheets on microfibrous-structured}

\section{Al-fibers for Pd-catalyzed CO oxidative coupling to dimethyl oxalate}

Chunzheng Wang ${ }^{\mathrm{a}, *}$, Weisong $\mathrm{Xu}^{\mathrm{a}}$, Zhengxing Qin ${ }^{\mathrm{a}}$, Xinmei Liu ${ }^{\mathrm{a}}$, Svetlana Mintova ${ }^{\mathrm{a}, \mathrm{b}}$

${ }^{\text {a }}$ State Key Laboratory of Heavy Oil Processing, College of Chemical Engineering, China University of Petroleum (East China), Qingdao 266580, China

${ }^{\mathrm{b}}$ Laboratoire Catalyse et Spectrochimie (LCS), Normandie Université, ENSICAEN, UNICAEN,

CNRS, 6 boulevard Maréchal Juin, Caen 14050, France

* Corresponding author. E-mail: czwang@upc.edu.cn 


\section{Abstract}

We reported the low-temperature synthesis of $\alpha-\mathrm{Al}_{2} \mathrm{O}_{3}$ nanosheets on the microfibrous-structured $\mathrm{Al}$ fibers at $800{ }^{\circ} \mathrm{C}$. The boehmite $(\mathrm{AlOOH})$ nanosheets were initially formed on the Al-fibers through in situ endogenous growth. Then the $\mathrm{AlOOH} / \mathrm{Al}$-fibers was transformed to the $\alpha-\mathrm{Al}_{2} \mathrm{O}_{3} / \mathrm{Al}$-fibers composite at $800^{\circ} \mathrm{C}$ by a single heating step. The low-temperature phase transformation was tentatively attributed to the $\mathrm{Al}$ metal in the $\mathrm{AlOOH} / \mathrm{Al}$-fibers. Palladium was then dispersed on the $\alpha-\mathrm{Al}_{2} \mathrm{O}_{3} / \mathrm{Al}-$ fibers composite, and the resulting $\mathrm{Pd} / \alpha-\mathrm{Al}_{2} \mathrm{O}_{3} / \mathrm{Al}$-fibers catalyst was examined in the strongly exothermic $\mathrm{CO}$ oxidative coupling to dimethyl oxalate (DMO) reaction. High $\mathrm{CO}$ conversion of $58 \%$ and DMO selectivity of $95 \%$ were obtained and maintained for at least $150 \mathrm{~h}$ using a feedgas of $\mathrm{CH}_{3} \mathrm{ONO} / \mathrm{CO} / \mathrm{N}_{2}(1 / 1.4 / 7.6$, mole $)$ at $150{ }^{\circ} \mathrm{C}$ with a gas hourly space velocity of $20000 \mathrm{~mL} \mathrm{~g}^{-1}$ $\mathrm{h}^{-1}$. Computational fluid dynamics calculations and experimental results indicated that the $\mathrm{Pd} / \alpha-$ $\mathrm{Al}_{2} \mathrm{O}_{3} / \mathrm{Al}$-fibers catalyst remarkably decreased the hot-spot temperature of catalyst bed due to its enhanced thermal conductivity.

Keywords: Structured catalyst; Alpha alumina; Nanosheet; Phase transformation; Aluminum fiber; Dimethyl oxalate. 


\section{Introduction}

Alpha alumina $\left(\alpha-\mathrm{Al}_{2} \mathrm{O}_{3}\right)$ is of fundamental and technological importance for plenty of applications in the petroleum industries and environmental protection [1-3]. In general, $\alpha-\mathrm{Al}_{2} \mathrm{O}_{3}$ is derived from the thermolysis of gibbsite, boehmite, other hydrated alumina and undergoes a lot of transitional phases $\left(\eta-, \gamma_{-}, \delta-, \theta-, \chi-, \kappa-\mathrm{Al}_{2} \mathrm{O}_{3}\right)[4,5]$. However, these methods commonly require a high calcination temperature above $1100{ }^{\circ} \mathrm{C}$ and thus lead to high energy consumption. This becomes a reason for developing a low-temperature synthesis procedure of $\alpha-\mathrm{Al}_{2} \mathrm{O}_{3}$. Several groups reported on the use of additives such as seeds, oxidants, chelating agents, mineralizers and special reactors (laser or microwave) to lower the formation temperature of $\alpha-\mathrm{Al}_{2} \mathrm{O}_{3}[6,7]$. Suchanek et al. reported the synthesis of $\alpha-\mathrm{Al}_{2} \mathrm{O}_{3}$ nanosheets using $\mathrm{AlOOH}$ under hydrothermal treatment in the presence of $\alpha-\mathrm{Al}_{2} \mathrm{O}_{3}$ seeds and additives $\left(\mathrm{H}_{2} \mathrm{O}_{2}, \mathrm{SiO}_{2}\right.$ and $\left.\mathrm{H}_{3} \mathrm{BO}_{3}\right)$ at $380-450{ }^{\circ} \mathrm{C}$ under 6.9-14.5 $\mathrm{MPa}[8,9]$.

The $\alpha-\mathrm{Al}_{2} \mathrm{O}_{3}$-based catalysts are usually loaded in the fixed-bed reactors as randomly packed pellets of several millimeters. Such packed beds suffer from the large pressure drop, low intraparticle/interbed heat transfer and irregular flow pattern, which is detrimental to high-throughput, diffusion-determining and strongly exothermic/endothermic reactions [10,11]. To solve these problems, $\alpha-\mathrm{Al}_{2} \mathrm{O}_{3}$ is directly manufactured into the structured foam and honeycomb monoliths, but the mechanical strength of the structure is very poor [12]. Furthermore, $\alpha-\mathrm{Al}_{2} \mathrm{O}_{3}$ is deposited on the structured foam $(\mathrm{Ni}, \mathrm{Al})$ and honeycomb (cordierite) monoliths by coating techniques, which combines the merits of $\alpha-\mathrm{Al}_{2} \mathrm{O}_{3}$ support with structured substances [13]. The catalysts using $\mathrm{Al}_{2} \mathrm{O}_{3}$-coated structured substances as supports, showed the high catalyst utilization and enhanced heat-transfer performance $[14,15]$. However, the conventional coating techniques are subjected to the nonuniformity and detachment of the coating layer as well as harmful contamination of the binder $[16,17]$. 
Recently, the conversion of non-petroleum syngas $\left(\mathrm{CO} / \mathrm{H}_{2}\right)$ into chemicals and liquid fuels is a promising alternative to the petrochemical-based routes [18]. The gas-phase carbonylation of methyl nitrite $\left(\mathrm{CH}_{3} \mathrm{ONO}\right)$ to dimethyl oxalate $\left(\mathrm{DMO},\left(\mathrm{CH}_{3} \mathrm{OCO}\right)_{2}\right)$ is a pivotal step from syngas to ethylene glycol (DMO hydrogenation) [19]. This process is self-closing and includes chemical-looping with two main reactions: (1) Pd-catalyzed $\mathrm{CO}$ oxidative coupling to DMO: $2 \mathrm{CH}_{3} \mathrm{ONO}+2 \mathrm{CO} \rightarrow 2 \mathrm{NO}+$ $\left(\mathrm{CH}_{3} \mathrm{OCO}\right)_{2}$; and (2) noncatalytic $\mathrm{CH}_{3} \mathrm{ONO}$ regeneration: $2 \mathrm{NO}+2 \mathrm{CH}_{3} \mathrm{OH}+1 / 2 \mathrm{O}_{2} \rightarrow 2 \mathrm{CH}_{3} \mathrm{ONO}$ $+\mathrm{H}_{2} \mathrm{O}$. The overall reaction $\left(2 \mathrm{CO}+2 \mathrm{CH}_{3} \mathrm{OH}+1 / 2 \mathrm{O}_{2} \rightarrow\left(\mathrm{CH}_{3} \mathrm{OCO}\right)_{2}+\mathrm{H}_{2} \mathrm{O}\right)$ is highly efficient and environmentally benign. However, the industrial $\mathrm{Pd} / \alpha-\mathrm{Al}_{2} \mathrm{O}_{3}$ catalyst for $\mathrm{CO}$ oxidative coupling to DMO, needs a high Pd content of 2 wt.\% (the-state-of-the-art), leading to a compromised economy of the DMO production [20]. The on-going efforts have been dedicated to reduce the Pd content by proper tuning of the $\mathrm{Pd}$ size/shape, Pd-support interactions and adding of a promoter [21-23]. Peng et al. reported a high-performance $\mathrm{Pd} / \alpha-\mathrm{Al}_{2} \mathrm{O}_{3}$ catalyst with Pd content of only 0.13 wt.\% [22]. Nevertheless, little attention is paid to the $\alpha-\mathrm{Al}_{2} \mathrm{O}_{3}$ support used in the strongly exothermic $\mathrm{CO}$ oxidative coupling to DMO $\left(\Delta H_{25}{ }^{\circ} \mathrm{C}=-159 \mathrm{~kJ} \mathrm{~mol}^{-1}\right)$. The real application of $\alpha-\mathrm{Al}_{2} \mathrm{O}_{3}$ a few millimeters in size, may provoke large temperature rise with undesired hot spot in the reactor bed, which decreases the product selectivity and even makes the temperature control difficult $[21,23]$. To overcome this problem, a structured $\mathrm{Pd}-\mathrm{Fe} / \alpha-\mathrm{Al}_{2} \mathrm{O}_{3}$-coated-cordierite catalyst was prepared, but the $\mathrm{Pd}$ loading was as high as 1.0 wt.\% [21]. Therefore, it is important to develop a highly efficient, low Pd-loaded catalyst with enhanced heat transfer for both fundamental study and commercial application.

Herein, we revealed the low-temperature synthesis method of $\alpha-\mathrm{Al}_{2} \mathrm{O}_{3}$ nanosheets on the microfibrous-structured Al-fibers through the phase transformation of $\mathrm{AlOOH}$ nanosheets at $800{ }^{\circ} \mathrm{C}$. Both the metal Al-promoted phase transformation of $\mathrm{AlOOH}$ and the formation of $\alpha-\mathrm{Al}_{2} \mathrm{O}_{3}$ were 
carefully studied. The $\mathrm{Pd} / \alpha-\mathrm{Al}_{2} \mathrm{O}_{3} / \mathrm{Al}$-fibers catalyst was prepared by incipient-wetness impregnation using the as-obtained $\alpha-\mathrm{Al}_{2} \mathrm{O}_{3} / \mathrm{Al}$-fibers composite, and was tested in the strongly exothermic $\mathrm{CO}$ oxidative coupling to DMO reaction. Such microfibrous-structured catalyst showed a combination of improved heat transfer, low pressure drop, good activity, and excellent stability. The computational fluid dynamics (CFD) simulation was carried out to probe the heat-transfer ability of the microfibrousstructured catalyst.

\section{Experimental}

\subsection{Catalyst preparation}

A thin fibers felt $(2.0 \mathrm{~m}$ length $\times 1.0 \mathrm{~m}$ width $\times \sim 1.3 \mathrm{~mm}$ thickness $)$ of $60-\mu \mathrm{m}$ Al-fibers $(99.9 \mathrm{wt} . \%$ Al) was employed as a substrate; it was purchased from Shanghai Xincai Network-microstructured Material Co. Ltd. (China). The circular Al-fibers $(8 \mathrm{~mm}$ diameter; equal to the internal diameter of fixed-bed reactor) were tailored from the purchased fibers felt, and treated with 0.1 wt. $\% \mathrm{NaOH}$ solution at $25{ }^{\circ} \mathrm{C}$ for $2 \mathrm{~min}$ to remove the protective oxide layers from the surface. Subsequently, the pre-treated Al-fibers were loaded into a quartz tube, and oxidized in steam flow at $120{ }^{\circ} \mathrm{C}$ for $6 \mathrm{~h}$ to form the boehmite $(\mathrm{AlOOH})$ nanosheets on the Al-fibers surface (denoted as AlOOH/Al-fibers) [24]. The as-prepared $\mathrm{AlOOH} / \mathrm{Al}$-fibers were heated to $800{ }^{\circ} \mathrm{C}$ in air with a ramping rate of $2{ }^{\circ} \mathrm{C} \mathrm{min}{ }^{-1}$ and kept at that temperature for $2 \mathrm{~h}$ to obtain the $\alpha-\mathrm{Al}_{2} \mathrm{O}_{3} / \mathrm{Al}$-fibers composite.

The catalysts with a theoretical Pd content of $0.3 \mathrm{wt} . \%$ were prepared, as described elsewhere [23]. $0.0128 \mathrm{~g}$ of palladium acetate $\left(\mathrm{Pd}\left(\mathrm{CH}_{3} \mathrm{COO}\right)_{2}, 47\right.$ wt.\% Pd, Sinopharm Chemical Reagent Co., Ltd., China) was dissolved in $3.7 \mathrm{~g}$ of toluene $\left(\mathrm{C}_{6} \mathrm{H}_{5} \mathrm{CH}_{3}\right)$ and the solution was used to impregnate $2.0 \mathrm{~g}$ of the $\alpha-\mathrm{Al}_{2} \mathrm{O}_{3} / \mathrm{Al}$-fibers composite. After drying at $100{ }^{\circ} \mathrm{C}$ for $2 \mathrm{~h}$, the pre-impregnated Al-fibers were calcined at $300{ }^{\circ} \mathrm{C}$ in air for $2 \mathrm{~h}$ to obtain the catalyst denoted as $\mathrm{Pd} / \alpha-\mathrm{Al}_{2} \mathrm{O}_{3} / \mathrm{Al}$-fibers. For reference, 
an $\alpha-\mathrm{Al}_{2} \mathrm{O}_{3}$ (60-80 mesh; Alfa Aesar (China) Chemical Co. Ltd.) support was used to prepare the $\mathrm{Pd} / \alpha-\mathrm{Al}_{2} \mathrm{O}_{3}$ catalyst by the same preparation method.

\subsection{Characterizations}

Scanning electron microscope (SEM) observations were conducted on a Hitachi S-4800 instrument. Transmission electron microscope (TEM) images were obtained with a FEI TECNAI G ${ }^{2}$ F30 instrument at $300 \mathrm{kV}$. The shell of the $\alpha-\mathrm{Al}_{2} \mathrm{O}_{3} / \mathrm{Al}$-fibers composite was carefully removed by a cutter knife and then the obtained powder (i.e., the shell) was used for the TEM analysis. X-ray diffraction (XRD) patterns of samples were recorded on a Rigaku Ultima IV diffractometer with $\mathrm{Cu} \mathrm{K} \alpha$ radiation (35 kV and $25 \mathrm{~mA}$ ). Diffuse reflectance infrared Fourier transform spectroscopy (DRIFTS) spectra were recorded in a Bruker Tensor 27 spectrometer equipped with a Harrick Scientific HVC-DRP-4 cell and a liquid $\mathrm{N}_{2}$ cooled mercury-cadmium-telluride (MCT) detector. The actual Pd loading was measured using inductively coupled plasma-atomic emission spectroscopy (ICP-AES) with a Thermo IRIS Intrepid II XSP apparatus. Prior to the analysis, the sample was dissolved in aqua regia. Pd ICP standard solutions with concentrations of 5, 10 and $20 \mu \mathrm{g} \mathrm{g}^{-1}$ were used to obtain the calibration curve. Nitrogen physisorption was performed at $-196{ }^{\circ} \mathrm{C}$ using a Quantachrome Quadrasorb-evo instrument. The specific surface area and pore size distribution were estimated using the Brunauer-Emmett-Teller (BET) theory and Barrett-Joyner-Halenda $(\mathrm{BJH})$ method based on the desorption branch of the isotherms. X-ray photoelectron spectroscopy (XPS) spectra were obtained on an Escalab 250xi spectrometer with an analyzer pass energy of $30.0 \mathrm{eV}$ and an $\mathrm{Al} \mathrm{K} \alpha \mathrm{X}$-ray source $(300 \mathrm{~W})$. The results were referenced to the adventitious carbon, $\mathrm{C} 1 \mathrm{~s}$ peak at $284.6 \mathrm{eV}$ prior to fitting the spectra. $\mathrm{H}_{2}$ temperature programmed reduction $\left(\mathrm{H}_{2}-\mathrm{TPR}\right)$ was conducted on a Tianjin XQ TP-5080 apparatus equipped with a thermal conductivity detector (TCD). $100 \mathrm{mg}$ of sample was treated with He (flow of 
$40 \mathrm{~mL} \min ^{-1}$ ) at $300{ }^{\circ} \mathrm{C}$ for $1 \mathrm{~h}$ and then cooled to $25^{\circ} \mathrm{C}$. Subsequently, a gas mixture of 5 vol. $\% \mathrm{H}_{2} / \mathrm{N}_{2}$ was introduced into the reactor at $40 \mathrm{~mL} \mathrm{~min}^{-1}$. After the baseline of TCD signal was steady, the sample was heated to $300{ }^{\circ} \mathrm{C}$ at $10{ }^{\circ} \mathrm{C} \mathrm{min}^{-1}$.

\subsection{Catalytic tests}

The catalytic behavior of the $\mathrm{Pd} / \alpha-\mathrm{Al}_{2} \mathrm{O}_{3} / \mathrm{Al}$-fibers and $\mathrm{Pd} / \alpha-\mathrm{Al}_{2} \mathrm{O}_{3}$ catalysts was tested in a vertical fixed-bed, continuous down-flow quartz tube microreactor (internal diameter of $8 \mathrm{~mm}$, length of $760 \mathrm{~mm}$ ) (Scheme 1) [25]. Three calibrated mass flow controllers were employed to regulate the flow rates of $\mathrm{N}_{2}, \mathrm{CO}$, the gas mixture of methyl nitrite $\left(\mathrm{CH}_{3} \mathrm{ONO}\right)$ and $\mathrm{N}_{2}$. The weight of the catalyst was $0.12 \mathrm{~g}$ at gas hourly space velocity (GHSV) of $20000 \mathrm{~mL} \mathrm{~g}^{-1} \mathrm{~h}^{-1}$ and $0.04 \mathrm{~g}$ at GHSV of 60000 $\mathrm{mL} \mathrm{g}^{-1} \mathrm{~h}^{-1}$. The reaction temperature was varied in the range of $120-200{ }^{\circ} \mathrm{C}$. Prior to the test, the catalyst was in situ activated by performing the CO oxidative coupling to DMO at $200{ }^{\circ} \mathrm{C}$ for $2 \mathrm{~h}$ with a gas mixture of $\mathrm{CH}_{3} \mathrm{ONO} / \mathrm{CO} / \mathrm{N}_{2}$ (1 / 1.4 / 7.6, mole) [23]. The outlet gas was analyzed by an online gas chromatography (GC; Shanghai Ouhua 9160, China) equipped with a thermal conductivity detector (TCD) and flame ionization detector (FID). The TCD and FID were connected to a ShinCarbon ST packed column (DIKMA) and Innowax PEG-20M capillary column (HP), respectively. The six-way valve for FID and partial gas pipelines were heated at $120{ }^{\circ} \mathrm{C}$ to avoid the condensation of reaction products. The calculations of the turnover frequency (TOF), CO conversion, DMO selectivity and "methanol + methyl formate" $(\mathrm{ME}+\mathrm{MF})$ selectivity were presented in the Supporting Information. 


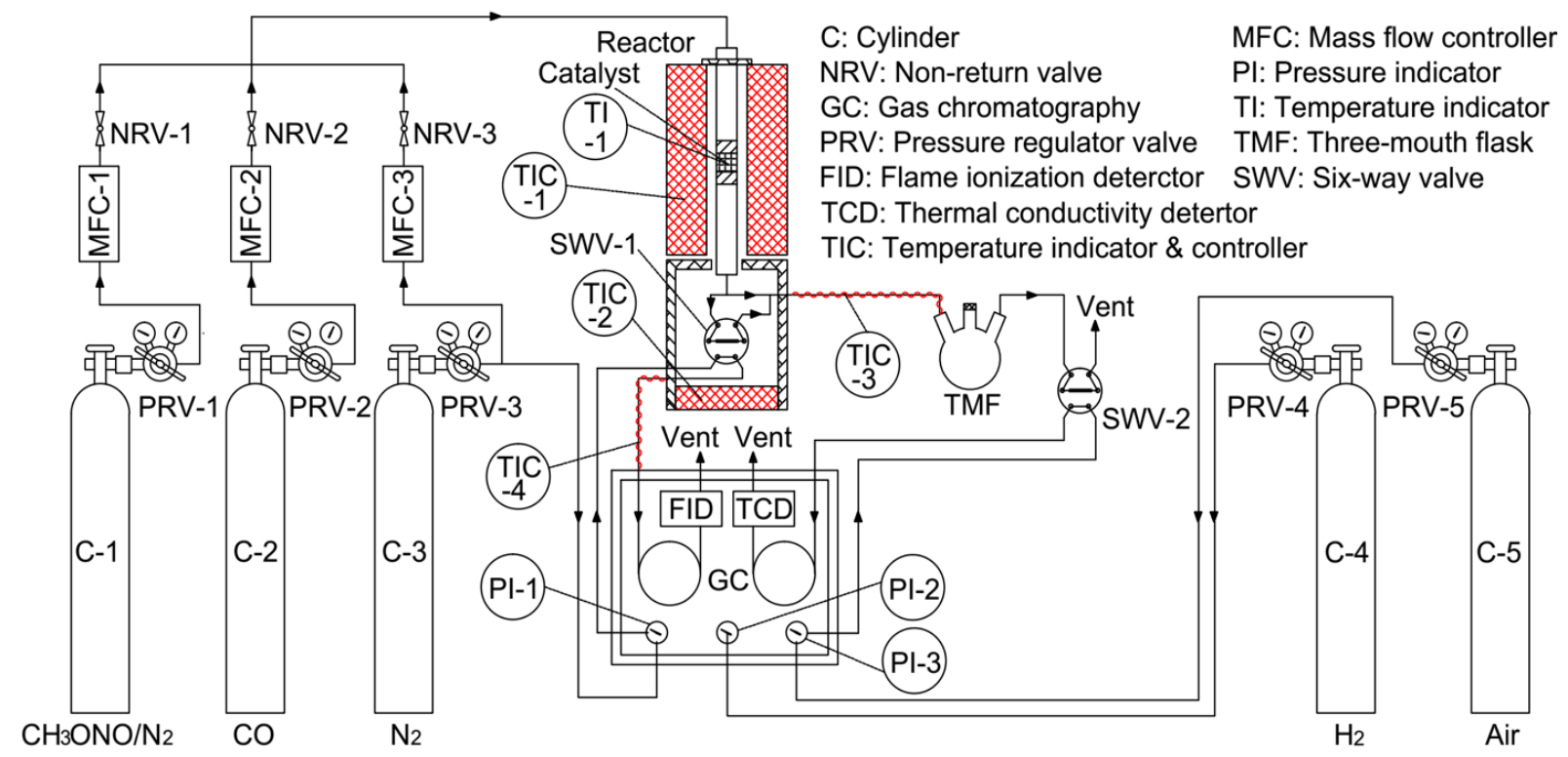

Scheme 1. Schematic diagram of the apparatus used for catalyst testing (the red parts are heated).

\section{Results and discussion}

\subsection{Low-temperature synthesis of $\alpha-\mathrm{Al}_{2} \mathrm{O}_{3}$ nanosheets on microfibrous-structured Al-fibers}

\subsubsection{Feature of $\alpha-\mathrm{Al}_{2} \mathrm{O}_{3} / \mathrm{Al}$-fibers composite}

Figure 1A schematically illustrates the endogenous growth of $\mathrm{AlOOH}$ nanosheets on the microfibrous-structured Al-fibers and the subsequent formation of $\alpha-\mathrm{Al}_{2} \mathrm{O}_{3}$ nanosheets by lowtemperature treatment (calcination). Circular Al-fibers with entirely open three-dimensional (3D) network, consisting of 10 vol.\% 60- $\mu \mathrm{m}$ Al-fibers and 90 vol.\% void volume were employed as the pristine substrate (Fig. 1B). The Al-fibers had a smooth surface as shown in the SEM images (Fig. S1). With the aid of the steam-only oxidation between $\mathrm{Al}$ metal and $\mathrm{H}_{2} \mathrm{O}$ at $120{ }^{\circ} \mathrm{C}\left(2 \mathrm{Al}+4 \mathrm{H}_{2} \mathrm{O} \rightarrow 2\right.$ $\mathrm{AlOOH}+3 \mathrm{H}_{2}$ ), the uniform and honeycomb-like $\mathrm{AlOOH}$ nanosheets were endogenously generated, and aligned to a nanosheet array (shell) on the Al-fibers (core) (Fig. 1C) [24]. The thickness of the $\mathrm{AlOOH}$ shell was about $0.7 \mu \mathrm{m}$ (inset of Fig. 1C) corresponding to an $\mathrm{AlOOH}$ content of 7.5 wt.\% [24]. The as-prepared $\mathrm{AlOOH} / \mathrm{Al}$-fibers composite was calcined in air at $800{ }^{\circ} \mathrm{C}$. The nanosheets were 
preserved (Fig. 1D) but the microstructure of these nanosheets was slightly changed, possibly due to the dehydroxylation of the AlOOH (Fig. S2). It should be noted that the metal Al (core) could not leak from the core-shell AlOOH/Al-fibers composite even at high-temperature treatment at $800{ }^{\circ} \mathrm{C}$ (melting point of $\mathrm{Al}$ is $660^{\circ} \mathrm{C}$ ), due to the obstruction of densely packed $\mathrm{AlOOH}$ nanosheets (shell). The similar observations were obtained on the $\mathrm{Al}$ alloys ( $\mathrm{Ni}-\mathrm{Al}$ and $\mathrm{Fe}-\mathrm{Al})$, indicating that the protective alumina scale on the alloys surface could provide excellent oxidation resistance above $1000{ }^{\circ} \mathrm{C}$ [26-28]. The characteristic diffraction peaks of metal Al (JCPDS 04-0787) were clearly observed in the pristine Alfibers (Fig. 1E, pattern a). The weak diffraction peaks at 28.2 and $49.3^{\circ} 2$ theta were attributed to the boehmite (JCPDS 21-1307) (Fig. 1E, pattern b). After the calcination at $800{ }^{\circ} \mathrm{C}$, the $\alpha-\mathrm{Al}_{2} \mathrm{O}_{3} / \mathrm{Al}_{\text {-fibers }}$ composite showed the formation of $\alpha-\mathrm{Al}_{2} \mathrm{O}_{3}$ phase (JCPDS 10-0173) confirmed by the appearance of the diffraction peaks at 25.6, 35.1, 43.4, 52.6, 57.5, 66.5 and $68.2^{\circ} 2$ theta (Fig. 1E, pattern c). In addition, the DRIFTS spectrum of AlOOH/Al-fibers composite contained five bands at 3336, 3126, 1066, 857 and $788 \mathrm{~cm}^{-1}$ that correspond to boehmite (Fig. 1F). The broad bands in the region $3600-3100 \mathrm{~cm}^{-1}$ were assigned to $\mathrm{O}-\mathrm{H}$ stretching vibrations of water, while the bands at $950-600 \mathrm{~cm}^{-1}$ are the Al-O bending stretching mode of $\alpha-\mathrm{Al}_{2} \mathrm{O}_{3}[29,30]$. The DRIFTS results were in a good agreement with the XRD results. The as-prepared $\alpha-\mathrm{Al}_{2} \mathrm{O}_{3} / \mathrm{Al}$-fibers composite had a BET specific surface area of $4.0 \mathrm{~m}^{2} \mathrm{~g}^{-1}$ and a total pore volume of $0.012 \mathrm{~cm}^{3} \mathrm{~g}^{-1}$ (including the Al-fibers) (Fig. 1G). After the Al-fibers content of $\sim 93$ wt. $\%$ was subtracted, it was calculated that the $\alpha-\mathrm{Al}_{2} \mathrm{O}_{3}$ shell had a large BET surface area of $\sim 50.0 \mathrm{~m}^{2} \mathrm{~g}_{\alpha-\mathrm{Al}_{2} \mathrm{O}_{3}}{ }^{-1}$ and total pore volume of $\sim 0.150 \mathrm{~cm}^{3} \mathrm{~g}_{\alpha-\mathrm{Al}_{2} \mathrm{O}_{3}}{ }^{-1}$. The $\alpha-$ $\mathrm{Al}_{2} \mathrm{O}_{3} / \mathrm{Al}$-fibers composite displayed a type-IV isotherm and mesopores with a size in the range of 4-19 nm. The appearance of type-H3 hysteresis loop at $\mathrm{P} / \mathrm{P}_{0}>0.5$ was attributed to the voids formed by stacking of $\alpha-\mathrm{Al}_{2} \mathrm{O}_{3}$ nanosheets (Fig. $1 \mathrm{G}$ ). 

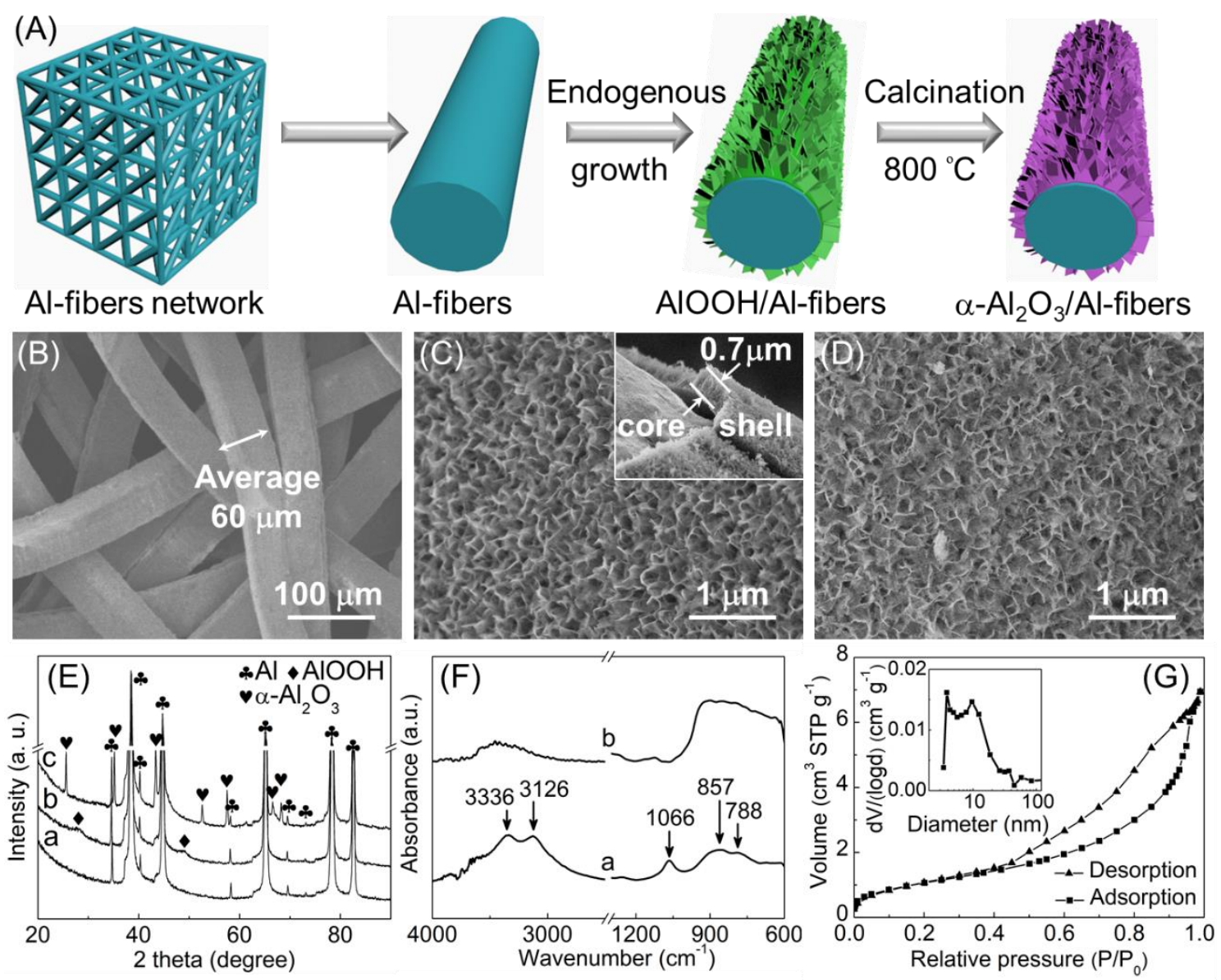

Fig. 1. (A) Schematic presentation of the top-down strategy applied for preparation of the core-shell $\alpha-\mathrm{Al}_{2} \mathrm{O}_{3} / \mathrm{Al}$-fibers composite. SEM images of (B) microfibrous-structured Al-fibers, (C) AlOOH/Alfibers (Inset: core(Al-fibers)-shell(AlOOH) structure) and (D) $\alpha-\mathrm{Al}_{2} \mathrm{O}_{3} / \mathrm{Al}$-fibers composite. (E) XRD patterns of the (a) Al-fibers substrate, (b) $\mathrm{AlOOH} / \mathrm{Al}$-fibers and (c) $\alpha-\mathrm{Al}_{2} \mathrm{O}_{3} / \mathrm{Al}$-fibers composite. (F) DRIFTS spectra of (a) AlOOH/Al-fibers and (b) $\alpha-\mathrm{Al}_{2} \mathrm{O}_{3} / \mathrm{Al}$-fibers composite, and (G) $\mathrm{N}_{2}$ sorption isotherm of the $\alpha-\mathrm{Al}_{2} \mathrm{O}_{3} / \mathrm{Al}$-fibers composite (Inset: $\mathrm{BJH}$ mesopore size distribution obtained from the desorption branch of the isotherm).

The shell of the $\alpha-\mathrm{Al}_{2} \mathrm{O}_{3} / \mathrm{Al}$-fibers composite was carefully removed by a cutter knife and the obtained powder (the shell) was analyzed by TEM (Fig. 2). TEM images showed that the shell of the $\alpha-\mathrm{Al}_{2} \mathrm{O}_{3} / \mathrm{Al}$-fibers composite was composed of nanosheets (Fig. 2A). This observation was in 
agreement with the nanosheet array observed in the SEM image (Fig. 1D). The nanosheets structure remained intact after calcination at $800{ }^{\circ} \mathrm{C}$, indicating the good thermal stability. The thickness of the nanosheets was 2-6 nm as measured by TEM (Fig. 2A). From the HRTEM image, the lattice spacing of the nanosheets of $0.25 \mathrm{~nm}$ was calculated, which possibly corresponds to the (104) lattice plane of $\alpha-\mathrm{Al}_{2} \mathrm{O}_{3}$ crystals (JCPDS 10-0173). This result further verified the formation of $\alpha-\mathrm{Al}_{2} \mathrm{O}_{3}$ on the $\alpha-$ $\mathrm{Al}_{2} \mathrm{O}_{3} / \mathrm{Al}$-fibers composite, which was consistent with the XRD and DRIFTS results (Fig. 1E and Fig. $1 \mathrm{~F})$.
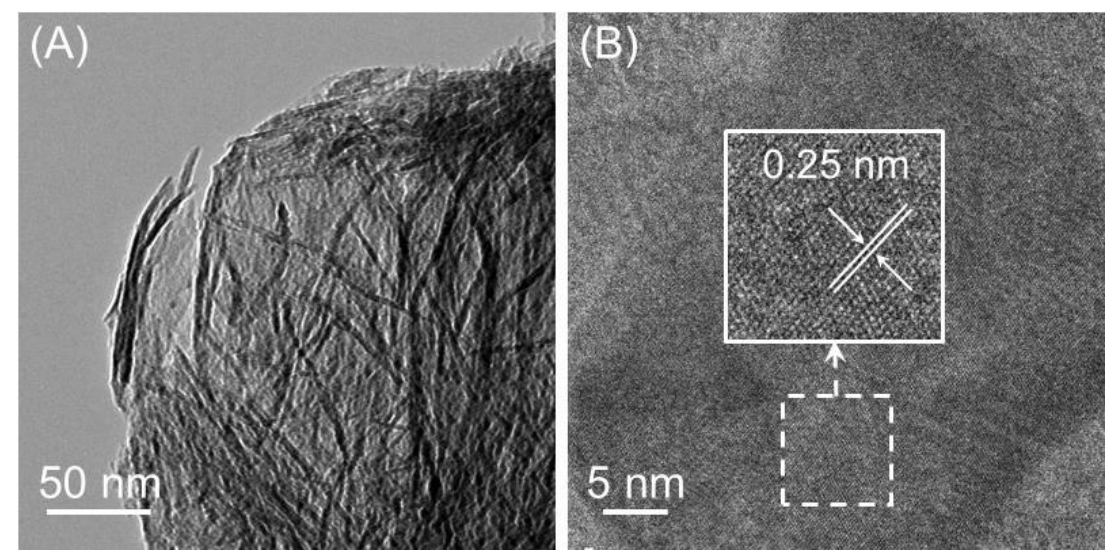

Fig. 2. TEM images of the $\alpha-\mathrm{Al}_{2} \mathrm{O}_{3} / \mathrm{Al}$-fibers composite: (A) scale bar, $\mathrm{M}=50 \mathrm{~nm}$ and (B) scale bar, $\mathrm{M}=5 \mathrm{~nm}$ (Inset: enlarged area of the composite with a lattice spacing of the nanosheets of $0.25 \mathrm{~nm}$ ).

\subsubsection{Phase transformation of AlOOH in the Al-fibers}

Fig. 3 shows the XRD patterns of the AlOOH/Al-fibers composite calcined at various temperatures. After calcination at $600{ }^{\circ} \mathrm{C}$, the diffraction peaks at 45.8 and $67.1^{\circ} 2$ theta were assigned to $\gamma-\mathrm{Al}_{2} \mathrm{O}_{3}$ (JCPDS 80-0956) (Fig. 3, pattern a). This revealed that the AlOOH on the Al-fibers could convert to $\gamma-\mathrm{Al}_{2} \mathrm{O}_{3}$ at $600{ }^{\circ} \mathrm{C}$. The peak intensity of $67.1^{\circ} 2$ theta increased gradually but the $\gamma-\mathrm{Al}_{2} \mathrm{O}_{3}$ phase remained unchanged with arising the calcination temperature from 600 to $750{ }^{\circ} \mathrm{C}$ (Fig. 3, patterns a-c). However, the $\mathrm{AlOOH}$ on the Al-fibers was transformed into $\alpha-\mathrm{Al}_{2} \mathrm{O}_{3}$ at $800{ }^{\circ} \mathrm{C}$ (Fig. 3, pattern d). The 
composite after calcination at $600{ }^{\circ} \mathrm{C}$ was calcined again at $800{ }^{\circ} \mathrm{C}$, and the XRD pattern was identical with that of the composite calcined at $800{ }^{\circ} \mathrm{C}$ (Fig. 3, patterns d,e). This suggested that the $\gamma-\mathrm{Al}_{2} \mathrm{O}_{3}$ on the Al-fibers converted to $\alpha-\mathrm{Al}_{2} \mathrm{O}_{3}$ at $800{ }^{\circ} \mathrm{C}$. This result confirmed that the $\mathrm{AlOOH}$ on the Al-fibers is transformed according to the following scheme: $\mathrm{AlOOH} \rightarrow \gamma-\mathrm{Al}_{2} \mathrm{O}_{3} \rightarrow \alpha-\mathrm{Al}_{2} \mathrm{O}_{3}$.

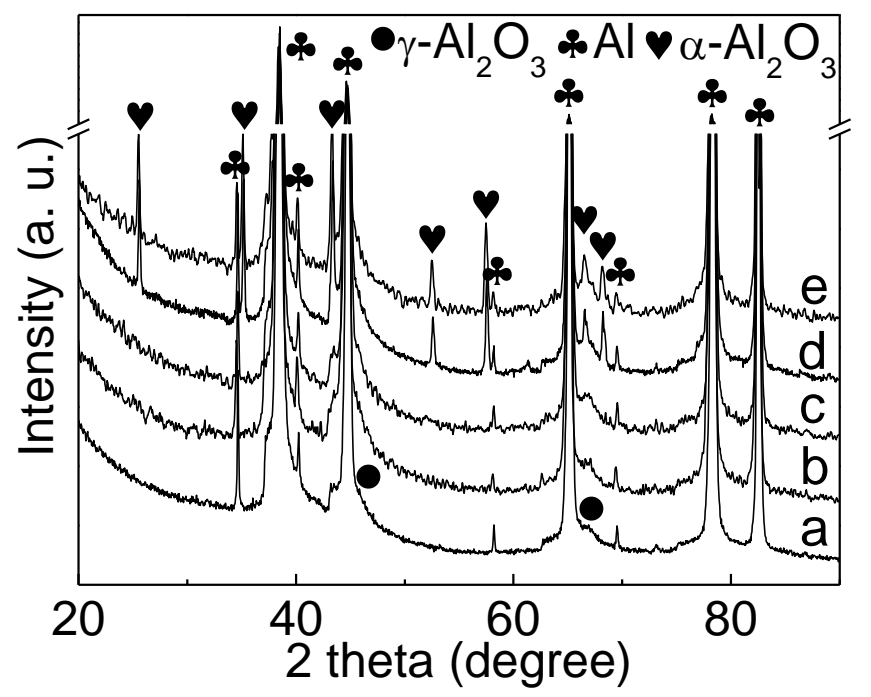

Fig. 3. XRD patterns of the AlOOH/Al-fibers composite after calcination: (a) $600{ }^{\circ} \mathrm{C}$ for $2 \mathrm{~h}$, (b) 700 ${ }^{\circ} \mathrm{C}$ for $2 \mathrm{~h}$, (c) $750{ }^{\circ} \mathrm{C}$ for $2 \mathrm{~h}$, (d) $800{ }^{\circ} \mathrm{C}$ for $2 \mathrm{~h}$, (e) $600{ }^{\circ} \mathrm{C}$ for $2 \mathrm{~h}$ and subsequent $800{ }^{\circ} \mathrm{C}$ for $2 \mathrm{~h}$.

Fig. 4 shows the XPS spectra of the Al 2p and O 1s regions for the AlOOH/Al-fibers composite before and after calcination. As shown in Fig. 4A, these four composites had a binding energy (BE) of $74.0-74.6 \mathrm{eV}$, which was attributed to $\mathrm{Al}^{3+}$ in alumina [31]. The absence of $\mathrm{Al} 2 \mathrm{p}$ peak at $72.5 \mathrm{eV}$ indicated that the $\mathrm{Al}-\mathrm{Al}$ bond ( $\mathrm{Al}$ metal) was not present on the surface of these four composites [32]. This further confirmed the SEM observation that the metal Al could not leak from the Al-fibers under calcination at $800{ }^{\circ} \mathrm{C}$ (Fig. 1D). The full width at half-maximum (FWHM) of $\mathrm{Al} 2 \mathrm{p}$ peak on the $\mathrm{AlOOH} / \mathrm{Al}$-fibers $(1.5 \mathrm{eV})$ without calcination was lower than of the other three composites (2.0-2.3 eV) (Fig. 4A and Table 1). The Al 2p peak with a characteristic FWHM of $1.5 \mathrm{eV}$ was attributed to boehmite [33], suggesting the presence of $\mathrm{AlOOH}$ on the surface of the AlOOH/Al-fibers. This result 
was consistent with the XRD and DRIFTS results (Fig. 1E and 1F). As shown in Fig. 4B, the broad O 1s spectra were decomposed into two component species: Al-O (530.7 eV) and Al-OH (532.1 eV) $[34,35]$. From the XPS results one can see that the peak area ratio of Al-O and Al-OH gradually increased, due to the desorption of hydroxyl groups at high temperature (Fig. 4B and Table 1).
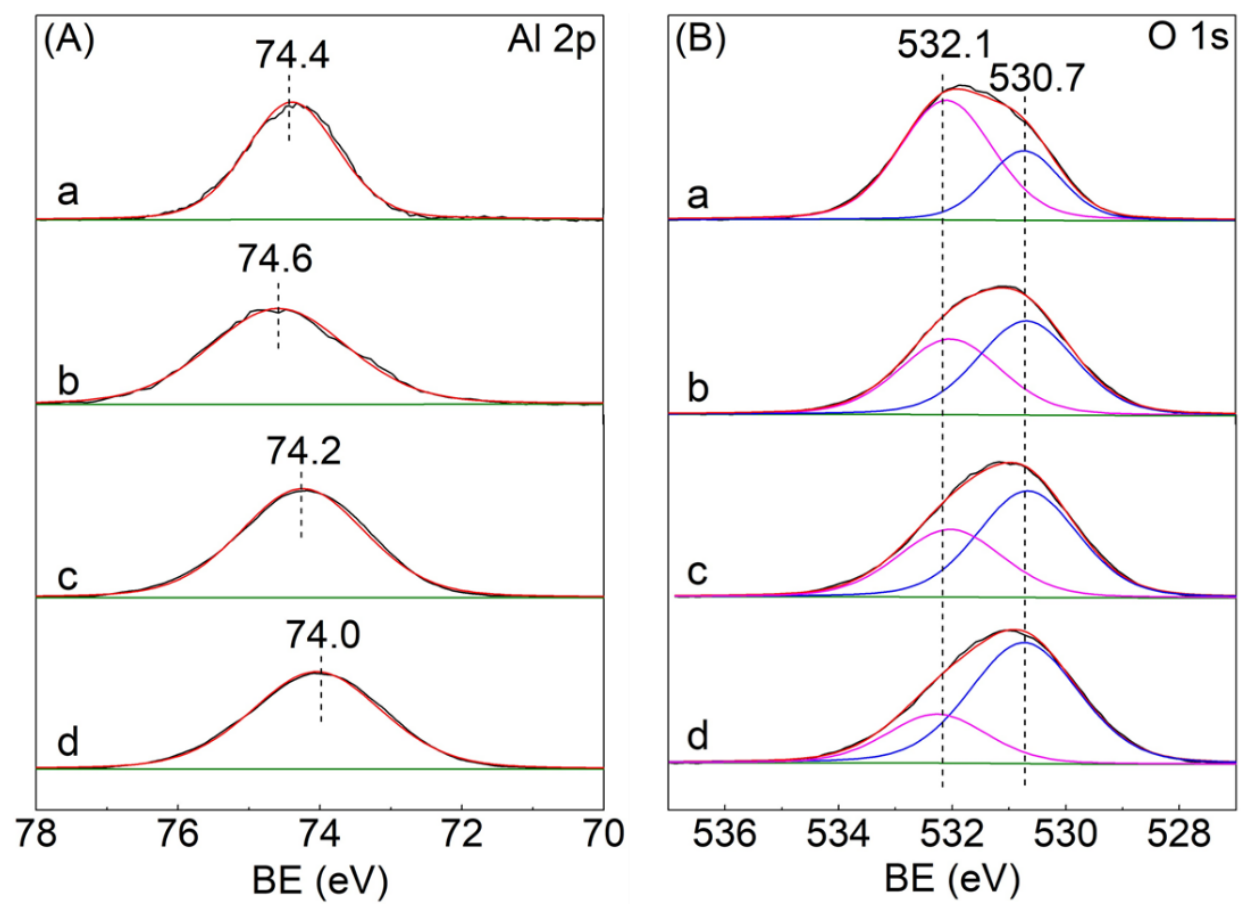

Fig. 4. XPS spectra of (A) $\mathrm{Al} 2 \mathrm{p}$ and (B) O 1s regions of the AlOOH/Al-fibers composite (a) without calcination and after calcination for $2 \mathrm{~h}$ at (b) $600{ }^{\circ} \mathrm{C}$, (c) $700{ }^{\circ} \mathrm{C}$ and (d) $800{ }^{\circ} \mathrm{C}$; the XPS peaks were deconvoluted using the Gaussian-Lorentzian sum function and Newton iteration method after a linear background subtraction.

Table 1. Parameters obtained from the XPS spectra ${ }^{a}$.

\begin{tabular}{|c|c|c|c|c|c|c|c|}
\hline \multirow[t]{2}{*}{ Sample $^{a}$} & \multicolumn{2}{|l|}{$\mathrm{Al} \mathrm{2p}$} & \multicolumn{2}{|c|}{$\mathrm{O} 1 \mathrm{~s}$ at $530.7 \mathrm{eV}$} & \multicolumn{2}{|c|}{$\mathrm{O} 1 \mathrm{~s}$ at $532.1 \mathrm{eV}$} & \multirow{2}{*}{$\frac{\mathrm{O} 1 \mathrm{~s}}{\text { Ratio }^{b}}$} \\
\hline & $\mathrm{BE}(\mathrm{eV})$ & FWHM (eV) & FWHM (eV) & Area & FWHM (eV) & Area & \\
\hline $\mathrm{a}$ & 74.4 & 1.5 & 1.9 & 738 & 1.5 & 1584 & 0.46 \\
\hline
\end{tabular}




\begin{tabular}{cccccccc}
$\mathrm{b}$ & 74.6 & 2.3 & 2.1 & 1172 & 2.0 & 977 & 1.20 \\
$\mathrm{c}$ & 74.2 & 2.0 & 2.2 & 1313 & 2.1 & 771 & 1.70 \\
$\mathrm{~d}$ & 74.0 & 2.1 & 2.1 & 1489 & 2.3 & 549 & 2.71 \\
\hline
\end{tabular}

${ }^{a} \mathrm{XPS}$ spectra of the AlOOH/Al-fibers composite without calcination (a) and after calcination for $2 \mathrm{~h}$ at (b) $600{ }^{\circ} \mathrm{C}$, (c) $700{ }^{\circ} \mathrm{C}$ and (d) $800{ }^{\circ} \mathrm{C}$.

${ }^{b}$ Area ratio of $\mathrm{O} 1 \mathrm{~s}$ peak at $530.7 \mathrm{eV}$ to the peak at $532.1 \mathrm{eV}$.

\subsubsection{Low-temperature synthesis of $\alpha-\mathrm{Al}_{2} \mathrm{O}_{3}$ : promotion of Al metal}

The low-temperature phase transformation from $\mathrm{AlOOH}$ to $\alpha-\mathrm{Al}_{2} \mathrm{O}_{3}$ was initially attributed to the presence of $\mathrm{Al}$ metal. Firstly, reference $\mathrm{AlOOH}$ nanosheets were synthesized from a bayerite precursor as described elsewhere (Fig. 5A, pattern a) [36]. Even though the average thickness of the reference AlOOH nanosheets (1-5 nm measured by TEM images) was similar to the counterpart of nanosheets of the AlOOH/Al-fibers (Fig. 2A) [36], the former was totally transformed into $\gamma-\mathrm{Al}_{2} \mathrm{O}_{3}$ after calcination at $800{ }^{\circ} \mathrm{C}$ (Fig. 5A, pattern b). This was consistent with the previous reports revealing that the boehmite could not convert to $\alpha-\mathrm{Al}_{2} \mathrm{O}_{3}$ at $800{ }^{\circ} \mathrm{C}[37,38]$. Secondly, to study the effect of the $\mathrm{Al}$ metal, the AlOOH/Al-fibers composite calcined at $600^{\circ} \mathrm{C}$ was treated with an excess of $\mathrm{NaOH}$ solution (4.0 wt.\%) to remove the $\mathrm{Al}$ metal. Note that the concentration of $\mathrm{NaOH}$ solution should be carefully controlled, otherwise the composite will be completely dissolved in a concentrated solution. After the treatment, the rest of the AlOOH/Al-fibers composite calcined at $600{ }^{\circ} \mathrm{C}$ showed the characteristic diffraction peaks corresponding to the $\gamma-\mathrm{Al}_{2} \mathrm{O}_{3}$ phase (Fig. 5B, pattern a). The rest of the AlOOH/Alfibers composite after the calcination at $600{ }^{\circ} \mathrm{C}$ and the subsequent $\mathrm{NaOH}$ treatment, was treated at 800 ${ }^{\circ} \mathrm{C}$ but the $\gamma-\mathrm{Al}_{2} \mathrm{O}_{3}$ crystalline phase remained (Fig. 5B, pattern b). Both $\gamma-\mathrm{Al}_{2} \mathrm{O}_{3}$ and $\mathrm{AlOOH}$ on the Al-fibers could transform to the $\alpha-\mathrm{Al}_{2} \mathrm{O}_{3}$ at $800{ }^{\circ} \mathrm{C}$ as previously stated (Fig. 3, patterns d,e) while only the $\gamma-\mathrm{Al}_{2} \mathrm{O}_{3}$ without the $\mathrm{Al}$-fibers could not (Fig. 5B). The phase transformation to $\alpha-\mathrm{Al}_{2} \mathrm{O}_{3}$ is governed 
by nucleation and grain growth mechanism $[39,40]$. It has been confirmed experimentally and by modeling that the $\alpha-\mathrm{Al}_{2} \mathrm{O}_{3}$ can be formed at low temperature $\left(900-1100{ }^{\circ} \mathrm{C}\right.$ ) on $\mathrm{Al}$ alloys such as $\mathrm{Fe}$ $\mathrm{Al}$ and $\mathrm{Ni}-\mathrm{Al}$, due to the promoted $\alpha-\mathrm{Al}_{2} \mathrm{O}_{3}$ nucleation at the oxide/metal interface $[7,41]$. It is thus reasonable to infer that the formation of $\alpha-\mathrm{Al}_{2} \mathrm{O}_{3}$ at $800{ }^{\circ} \mathrm{C}$ was possibly attributed to the $\mathrm{Al}$ metal in the AlOOH/Al-fibers composite, which lowered the nucleation energy barrier of $\alpha-\mathrm{Al}_{2} \mathrm{O}_{3}$ at the oxide/Al metal interface.
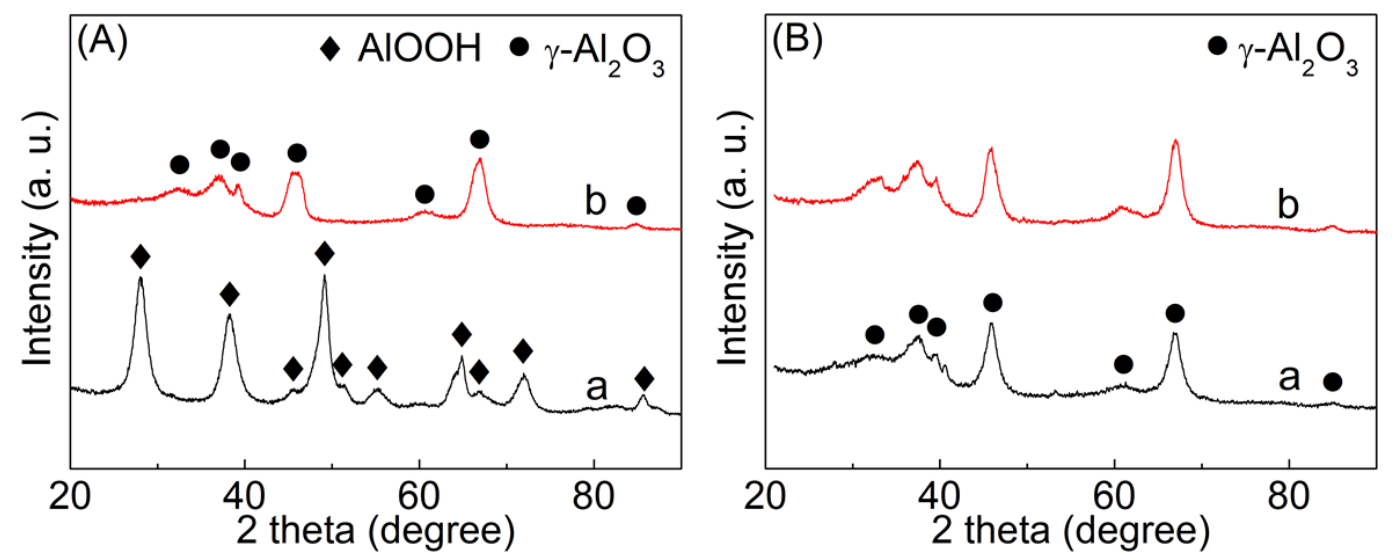

Fig. 5. (A) XRD patterns of the reference boehmite nanosheets (a) before and (b) after calcination at $800{ }^{\circ} \mathrm{C}$. (B) XRD patterns of AlOOH/Al-fibers composite (a) calcined at $600{ }^{\circ} \mathrm{C}$ for $2 \mathrm{~h}$ and then treated with an excess of $\mathrm{NaOH}$ solution (4.0 wt.\%) for $24 \mathrm{~h}$, and (b) calcined at $600{ }^{\circ} \mathrm{C}$, treated with $\mathrm{NaOH}$ solution and then calcined at $800{ }^{\circ} \mathrm{C}$ for $2 \mathrm{~h}$.

\subsection{Microfibrous-structured $\mathrm{Pd} / \alpha-\mathrm{Al}_{2} \mathrm{O}_{3} /$ Al-fibers catalyst for $\mathrm{CO}$ oxidative coupling to DMO}

\subsubsection{Features of $\mathrm{Pd} / \alpha-\mathrm{Al}_{2} \mathrm{O}_{3} / \mathrm{Al}$-fibers catalyst}

The $\mathrm{Pd} / \alpha-\mathrm{Al}_{2} \mathrm{O}_{3} / \mathrm{Al}$-fibers catalyst was prepared by incipient-wetness impregnation method using the as-prepared $\alpha-\mathrm{Al}_{2} \mathrm{O}_{3} / \mathrm{Al}$-fibers as support. As shown in Fig. 6A, the nanosheet array of $\alpha-\mathrm{Al}_{2} \mathrm{O}_{3}$ was well retained after the Pd loading. No diffraction peaks of PdO (JCPDS 88-2434) and Pd (JCPDS 01-1201) were detectable except the peaks corresponding to $\mathrm{Al}$ and $\alpha-\mathrm{Al}_{2} \mathrm{O}_{3}$, possibly due to a good 
Pd dispersion (Fig. 6B). In fact, the Pd was homogeneously dispersed on the $\alpha-\mathrm{Al}_{2} \mathrm{O}_{3} / \mathrm{Al}_{-}$-fibers composite, with an average particle size of $4.4 \pm 0.9 \mathrm{~nm}$ (Fig. 6C). The stacks of nanosheets of the catalyst were clearly observed, consistent with the catalyst support (Fig. 2A and Fig. 6C). The Pd/ $\alpha-$ $\mathrm{Al}_{2} \mathrm{O}_{3} / \mathrm{Al}$-fibers catalyst contains mesopores with a size of 4-19 $\mathrm{nm}$ and the BET specific surface area is $3.9 \mathrm{~m}^{2} \mathrm{~g}^{-1}$ with a total pore volume of $0.011 \mathrm{~cm}^{3} \mathrm{~g}^{-1}$ (including the Al-fibers mass), which were almost equal to the $\alpha-\mathrm{Al}_{2} \mathrm{O}_{3} / \mathrm{Al}$-fibers composite (Fig. $1 \mathrm{G}$ and Fig. 6D).
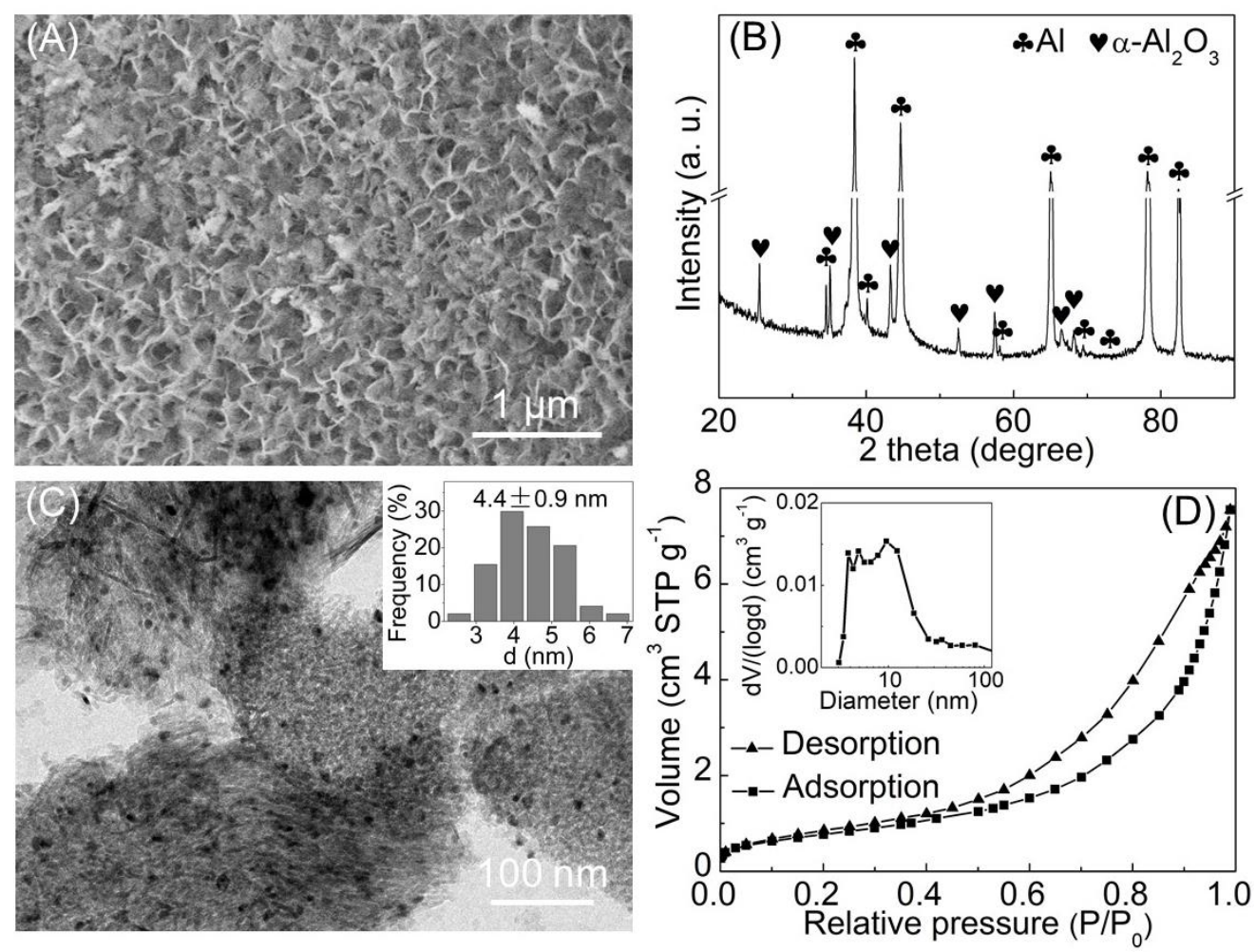

Fig. 6. (A) SEM image, (B) XRD pattern, (C) TEM image and (D) $\mathrm{N}_{2}$ sorption isotherm (Inset: BJH mesopore size distribution obtained from the desorption branch of the isotherms) of the $\mathrm{Pd} / \alpha-$ $\mathrm{Al}_{2} \mathrm{O}_{3} / \mathrm{Al}$-fibers catalyst.

\subsubsection{Catalytic performance of $\mathrm{Pd} / \alpha-\mathrm{Al}_{2} \mathrm{O}_{3} / \mathrm{Al}$-fibers catalyst}

The microfibrous-structured $\mathrm{Pd} / \alpha-\mathrm{Al}_{2} \mathrm{O}_{3} / \mathrm{Al}$-fibers catalyst was tested in the $\mathrm{CO}$ oxidative coupling to DMO using a GHSV of $20000 \mathrm{~mL} \mathrm{~g}^{-1} \mathrm{~h}^{-1}$ and a feedgas of $\mathrm{CH}_{3} \mathrm{ONO} / \mathrm{CO} / \mathrm{N}_{2}$ (1 / 1.4 / 7.6, mole). Compared to the reference catalyst of $\mathrm{Pd} / \alpha-\mathrm{Al}_{2} \mathrm{O}_{3}$, the $\mathrm{Pd} / \alpha-\mathrm{Al}_{2} \mathrm{O}_{3} / \mathrm{Al}$-fibers delivered similar $\mathrm{CO}$ 
conversion, DMO selectivity and "methanol + methyl formate" (ME + MF) selectivity in the range of 120-140 ${ }^{\circ} \mathrm{C}$ (Fig. 7). Interestingly, the $\mathrm{Pd} / \alpha-\mathrm{Al}_{2} \mathrm{O}_{3} / \mathrm{Al}$-fibers showed higher $\mathrm{CO}$ conversion, DMO selectivity, and lower "ME $+\mathrm{MF}$ " selectivity than the reference $\mathrm{Pd} / \alpha-\mathrm{Al}_{2} \mathrm{O}_{3}$ catalyst at temperatures ranging from 150 to $170{ }^{\circ} \mathrm{C}$ (Fig. 7). This evolution behavior was initially assigned to the different thermal conductivity of microfibrous-structured Al-fibers and the $\alpha-\mathrm{Al}_{2} \mathrm{O}_{3}$. It should be pointed out that the $\mathrm{CO}$ oxidative coupling to DMO is highly exothermic $\left(\Delta H_{25}{ }^{\circ} \mathrm{C}=-169 \mathrm{~kJ} \mathrm{~mol}^{-1}\right)$, which may induce large temperature rise with unexpected hot spot in the reactor bed [23]. To examine the reaction heat effect, the thermocouple was inserted in the upper side of the catalyst bed. For example, the temperature rise detected (the temperature obtained from the thermocouple minus the reactor wall temperature of $150{ }^{\circ} \mathrm{C}$ ) was $5{ }^{\circ} \mathrm{C}$ on the $\mathrm{Pd} / \alpha-\mathrm{Al}_{2} \mathrm{O}_{3} / \mathrm{Al}$-fibers catalyst and $11{ }^{\circ} \mathrm{C}$ on the $\mathrm{Pd} / \alpha-\mathrm{Al}_{2} \mathrm{O}_{3}$ catalyst. The decomposition of the $\mathrm{CH}_{3} \mathrm{ONO}$ reactant $\left(4 \mathrm{CH}_{3} \mathrm{ONO} \rightarrow \mathrm{CH}_{3} \mathrm{OCHO}+2 \mathrm{CH}_{3} \mathrm{OH}+4 \mathrm{NO}\right)$ was very sensitive to the reaction temperature $[42,43]$, and was boosted in the range of $150-170{ }^{\circ} \mathrm{C}$ on the $\mathrm{Pd} / \alpha-\mathrm{Al}_{2} \mathrm{O}_{3}$ catalyst. It was concluded that the low temperature rise inhibited the inefficient decomposition of the $\mathrm{CH}_{3} \mathrm{ONO}$ reactant and thus led to the enhanced activity on the $\mathrm{Pd} / \alpha-\mathrm{Al}_{2} \mathrm{O}_{3} / \mathrm{Al}$ fibers catalyst. Clearly, our $\mathrm{Pd} / \alpha-\mathrm{Al}_{2} \mathrm{O}_{3} / \mathrm{Al}$-fibers catalyst exhibited better conversion and selectivity at high temperature of $150-170^{\circ} \mathrm{C}$, which would be an advantageous feature compared to the reference $\mathrm{Pd} / \alpha-\mathrm{Al}_{2} \mathrm{O}_{3}$ catalyst, by considering the strong exothermicity of the $\mathrm{CO}$ oxidative coupling to DMO.
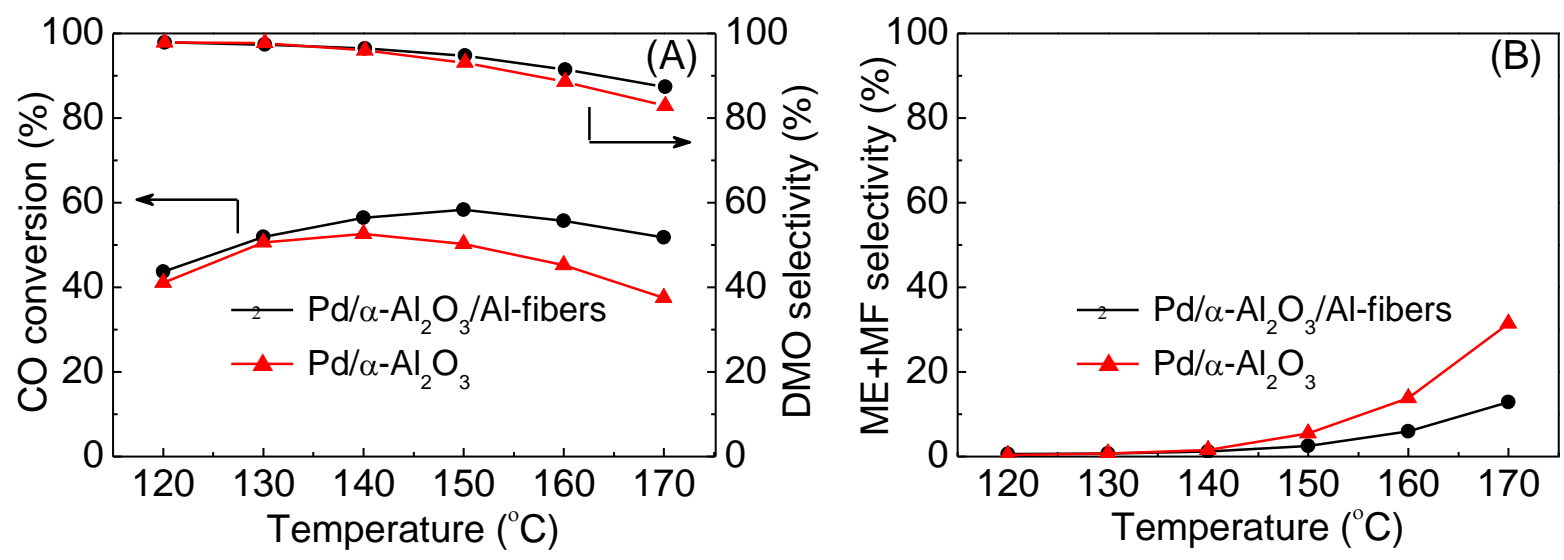
Fig. 7. (A) CO conversion, DMO selectivity and (B) "methanol + methyl formate" (ME $+\mathrm{MF})$ selectivity for temperature-dependent $\mathrm{CO}$ oxidative coupling to $\mathrm{DMO}$ on the $\mathrm{Pd} / \alpha-\mathrm{Al}_{2} \mathrm{O}_{3} / \mathrm{Al}$-fibers and $\mathrm{Pd} / \alpha-\mathrm{Al}_{2} \mathrm{O}_{3}$ catalysts. Reaction conditions: $0.12 \mathrm{~g}$ catalyst, $\mathrm{CH}_{3} \mathrm{ONO} / \mathrm{CO} / \mathrm{N}_{2}=1 / 1.4 / 7.6$ (mole), GHSV $=20000 \mathrm{~mL} \mathrm{~g}^{-1} \mathrm{~h}^{-1}, 1$ bar. Each point was an average of 3 measurements conducted. The DMO and "ME + MF" selectivity were based on the $\mathrm{CO}$ and $\mathrm{CH}_{3} \mathrm{ONO}$, respectively (details were provided in the Supporting Information).

The catalyst characteristics and intrinsic activity (i.e., TOF) of the $\mathrm{Pd} / \alpha-\mathrm{Al}_{2} \mathrm{O}_{3} / \mathrm{Al}$-fibers and $\mathrm{Pd} / \alpha-$ $\mathrm{Al}_{2} \mathrm{O}_{3}$ were summarized in Table 2 . The Pd loadings of the two catalysts were determined to be 0.25 wt.\% and 0.26 wt. $\%$ by ICP-AES analysis. The average Pd particle sizes $(d)$ in the $\mathrm{Pd} / \alpha-\mathrm{Al}_{2} \mathrm{O}_{3} / \mathrm{Al}-$ fibers and $\mathrm{Pd} / \alpha-\mathrm{Al}_{2} \mathrm{O}_{3}$ were $4.4 \mathrm{~nm}$ and $2.0 \mathrm{~nm}$ (TEM images in Fig. 6C and Fig. S3), corresponding to the Pd dispersion $(D)$ of 0.25 and 0.56 , respectively (the $D$ was calculated using the formula $D=$ $1.12 / d$ [23]. Similar $\mathrm{H}_{2}$-temperature programmed reduction (TPR) curves for the two catalysts were measured, which showed the catalysts could be completely reduced at about $120{ }^{\circ} \mathrm{C}$ (Fig. S4). As a control experiment, the $\mathrm{CO}$ conversion was decreased to be $<6 \%$ at $120{ }^{\circ} \mathrm{C}$ and GHSV of $60000 \mathrm{~mL}$ $\mathrm{g}^{-1} \mathrm{~h}^{-1}$ for the TOF calculation. The TOFs of 0.7 and $0.5 \mathrm{~s}^{-1}$ for the two catalysts, respectively were obtained, indicating comparable intrinsic activity. Clearly, the $\mathrm{Pd} / \alpha-\mathrm{Al}_{2} \mathrm{O}_{3} / \mathrm{Al}$-fibers and $\mathrm{Pd} / \alpha-\mathrm{Al}_{2} \mathrm{O}_{3}$ catalysts have similar Pd contents, reduction behavior, comparable Pd particle size and intrinsic activity. These results suggested that the $\alpha-\mathrm{Al}_{2} \mathrm{O}_{3} / \mathrm{Al}$-fibers composite is a promising alternative to the conventional $\alpha-\mathrm{Al}_{2} \mathrm{O}_{3}$ for the $\mathrm{CO}$ oxidative coupling to DMO.

Table 2 Content, property and activity of the $\mathrm{Pd} / \alpha-\mathrm{Al}_{2} \mathrm{O}_{3} / \mathrm{Al}$-fibers and $\mathrm{Pd} / \alpha-\mathrm{Al}_{2} \mathrm{O}_{3}$ catalysts .

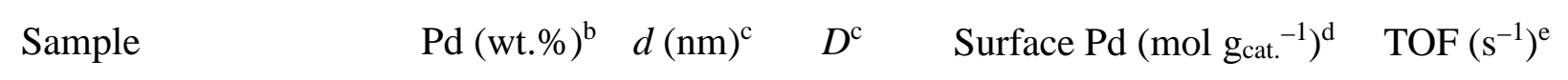




\begin{tabular}{lccccc}
\hline $\mathrm{Pd} / \alpha-\mathrm{Al}_{2} \mathrm{O}_{3} / \mathrm{Al}$-fibers & 0.25 & 4.4 & 0.25 & $6.6 \times 10^{-6}$ & 0.7 \\
$\mathrm{Pd} / \alpha-\mathrm{Al}_{2} \mathrm{O}_{3}$ & 0.26 & 2.0 & 0.56 & $1.4 \times 10^{-5}$ & 0.5 \\
\hline
\end{tabular}

${ }^{\mathrm{a}}$ Reaction conditions: $0.04 \mathrm{~g}$ catalyst, $120{ }^{\circ} \mathrm{C}$, GHSV $=60000 \mathrm{~mL} \mathrm{~g}^{-1} \mathrm{~h}^{-1}, \mathrm{CH}_{3} \mathrm{ONO} / \mathrm{CO} / \mathrm{N}_{2}=1 / 1.4$ / 7.6 (mole), 1 bar.

${ }^{\mathrm{b}} \mathrm{Pd}$ content determined by ICP-AES analysis.

${ }^{\mathrm{c}} \mathrm{Pd}$ particle size $(d)$ obtained from TEM images in Fig. 6C and Fig. S3, and Pd dispersion $(D)$ calculated by the formula: $D=1.12 / d[23]$.

${ }^{\mathrm{d}}$ Surface Pd atoms determined by Pd dispersion $(D)$ and Pd content.

${ }^{\text {e }}$ TOF based on the CO conversion and surface Pd atoms.

\subsubsection{Heat transfer enhancement}

As previously stated, our main efforts were focused on the development of a microfibrousstructured catalyst with a combination of high catalytic performance and excellent thermal conductivity. To probe the heat-transfer ability of our catalyst, the $\mathrm{R}$ was conducted to obtain the temperature distribution in the microfibrous-structured bed of $\mathrm{Pd} / \alpha-\mathrm{Al}_{2} \mathrm{O}_{3} / \mathrm{Al}$-fibers and randomly packed bed of $\mathrm{Pd} / \alpha-\mathrm{Al}_{2} \mathrm{O}_{3}$ catalysts. As shown in Fig. $8 \mathrm{~A}$, the tubular reactor was divided into three parts: one isothermal section and two adiabatic sections. The detailed CFD model and calculation methods were described in the Supporting Information. Fig. 8B shows the steady-state temperature distribution on the microfibrous-structured $\mathrm{Pd} / \alpha-\mathrm{Al}_{2} \mathrm{O}_{3} / \mathrm{Al}$-fibers and the $\mathrm{Pd} / \alpha-\mathrm{Al}_{2} \mathrm{O}_{3}$ catalysts. The released reaction heat on the two catalysts was similar due to the comparable CO conversion $\left(58 \%\right.$ vs. $50 \%$ at $150{ }^{\circ} \mathrm{C}$, Fig. 7A) under identical reaction conditions. However, the reactor' temperature distribution of the $\mathrm{Pd} / \alpha-\mathrm{Al}_{2} \mathrm{O}_{3} / \mathrm{Al}$-fibers was more homogeneous than of the $\mathrm{Pd} / \alpha-\mathrm{Al}_{2} \mathrm{O}_{3}$ (Fig. 8B); the former showed a 
hot spot with a temperature rise of $8{ }^{\circ} \mathrm{C}$, which was much lower than the latter of $30{ }^{\circ} \mathrm{C}$ (the highest temperature of CFD simulation minus the reactor wall temperature of $150{ }^{\circ} \mathrm{C}$ ). The low temperature rise for the $\mathrm{Pd} / \alpha-\mathrm{Al}_{2} \mathrm{O}_{3} / \mathrm{Al}$-fibers catalyst was unambiguously attributed to the high thermal conductivity of the microfibrous-structured Al-fibers, which rapidly dissipated a large amount of reaction heat $[44,45]$. Notably, the trend of temperature rise by CFD simulation was consistent with the experimental observation using a thermocouple $\left(5\right.$ vs. $8{ }^{\circ} \mathrm{C}$ on the $\mathrm{Pd} / \alpha-\mathrm{Al}_{2} \mathrm{O}_{3} / \mathrm{Al}$-fibers catalyst; 11 vs. $30{ }^{\circ} \mathrm{C}$ on the $\mathrm{Pd} / \alpha-\mathrm{Al}_{2} \mathrm{O}_{3}$ reference catalyst).

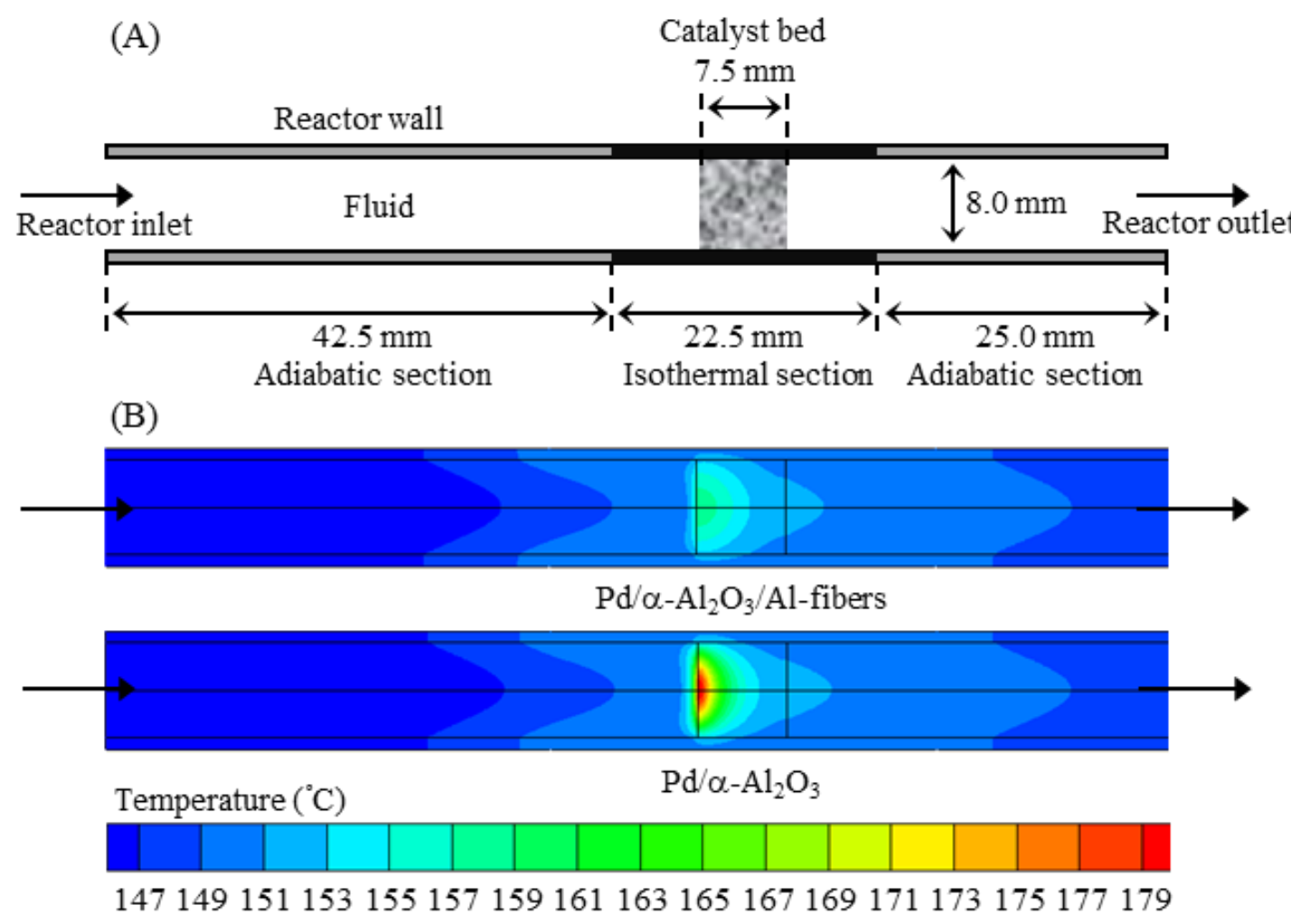

Fig. 8. (A) Schematic diagram of the system for CFD calculation, and (B) reactor temperature distribution obtained by the steady-state CFD simulation on the $\mathrm{Pd} / \alpha-\mathrm{Al}_{2} \mathrm{O}_{3} / \mathrm{Al}$-fibers catalyst and reference $\mathrm{Pd} / \alpha-\mathrm{Al}_{2} \mathrm{O}_{3}$ catalyst.

\subsubsection{Stability}

To investigate the long-term stability of the catalyst, an experiment was run at $150{ }^{\circ} \mathrm{C}$ for $150 \mathrm{~h}$ on 
the microfibrous-structured $\mathrm{Pd} / \alpha-\mathrm{Al}_{2} \mathrm{O}_{3} / \mathrm{Al}$-fibers catalyst. The catalyst showed a good stability throughout the $150 \mathrm{~h}$ test, exhibiting a CO conversion of $\sim 58 \%$ and DMO selectivity of $\sim 95 \%$ (Fig. 9A). The diffraction peaks of PdO (JCPDS 88-2434) and Pd (JCPDS 01-1201) were still not detectable for the used catalyst after $150 \mathrm{~h}$ test (Fig. S5). The TEM image showed Pd nanoparticles with an average size of $4.5 \pm 0.6 \mathrm{~nm}$ (Fig. S6), almost equal to that of the catalyst before the test $(4.4 \pm 0.9 \mathrm{~nm}$, Fig. 6C). This suggested that the $\mathrm{Pd} / \alpha-\mathrm{Al}_{2} \mathrm{O}_{3} / \mathrm{Al}$-fibers catalyst was resistant to the sintering of $\mathrm{Pd}$ nanoparticles. A noteworthy feature of the used catalyst was that the nanosheet array of $\alpha-\mathrm{Al}_{2} \mathrm{O}_{3}$ remained unaltered, confirmed by SEM (Fig. 9B,C) and XRD (Fig. S5) characterizations.

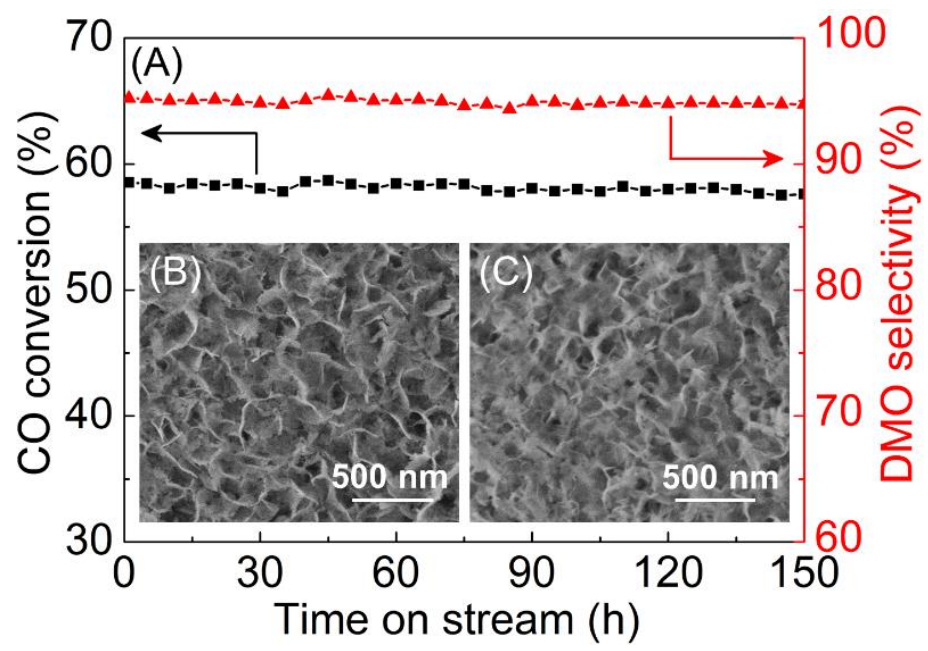

Fig. 9. (A) Durability performance of the $\mathrm{Pd} / \alpha-\mathrm{Al}_{2} \mathrm{O}_{3} / \mathrm{Al}$-fibers catalyst, and $\mathrm{SEM}$ images of (B) fresh and (C) used $\mathrm{Pd} / \alpha-\mathrm{Al}_{2} \mathrm{O}_{3} / \mathrm{Al}$-fibers catalyst after $150 \mathrm{~h}$ test. Reaction conditions: $0.12 \mathrm{~g}$ catalyst, $\mathrm{CH}_{3} \mathrm{ONO} / \mathrm{CO} / \mathrm{N}_{2}=1 / 1.4 / 7.6$ (mole), GHSV $=20000 \mathrm{~mL} \mathrm{~g}^{-1} \mathrm{~h}^{-1}, 150{ }^{\circ} \mathrm{C}, 1$ bar. Each point was an average of 5 measurements conducted.

\section{Conclusions}

The $\alpha-\mathrm{Al}_{2} \mathrm{O}_{3}$ nanosheets on the microfibrous-structured Al-fibers have been prepared through the phase transformation of boehmite nanosheets at temperature as low as $800^{\circ} \mathrm{C}$. The presence of $\mathrm{Al}$ metal 
in the Al-fibers is responsible for the low-temperature phase transformation to $\alpha-\mathrm{Al}_{2} \mathrm{O}_{3}$. Such $\alpha$ $\mathrm{Al}_{2} \mathrm{O}_{3} / \mathrm{Al}$-fibers, with enhanced heat transfer and low pressure drop, is a promising alternative to the conventional $\alpha-\mathrm{Al}_{2} \mathrm{O}_{3}$ support in some industrial and environmental catalysis. As an example, the $\mathrm{Pd} / \alpha-\mathrm{Al}_{2} \mathrm{O}_{3} / \mathrm{Al}$-fibers catalyst is prepared via incipient-wetness impregnation, and tested in the strongly exothermic CO oxidative coupling to dimethyl oxalate (DMO). The catalyst with a low Pd loading of 0.25 wt. $\%$ exhibits a CO conversion of $58 \%$ and DMO selectivity of $95 \%$ with a feedgas of $\mathrm{CH}_{3} \mathrm{ONO} / \mathrm{CO} / \mathrm{N}_{2}(1 / 1.4 / 7.6$, mole $)$ at $150{ }^{\circ} \mathrm{C}$ with a large gas hourly space velocity of 20000 $\mathrm{mL} \mathrm{g}^{-1} \mathrm{~h}^{-1}$. The $\mathrm{Pd} / \alpha-\mathrm{Al}_{2} \mathrm{O}_{3} / \mathrm{Al}$-fibers catalyst showed high stability during the continuous test of 150 h. The $\mathrm{Pd} / \alpha-\mathrm{Al}_{2} \mathrm{O}_{3} / \mathrm{Al}$-fibers catalyst effectively inhibited the side reaction and showed a higher activity compared to the conventional $\mathrm{Pd} / \alpha-\mathrm{Al}_{2} \mathrm{O}_{3}$ catalyst, resulted from the decreased temperature of the catalyst bed. Furthermore, computational fluid dynamics calculations and experimental measurements demonstrated the large reduction of hot-spot temperature thanks to the enhanced thermal conductivity originated from the microfibrous-structured Al-fibers.

\section{Acknowledgements}

This work was supported by the China Postdoctoral Science Foundation (2017M622311), Natural Science Foundation of China (21706285), Fundamental Research Funds for the Central Universities (18CX02148A, 18CX02013A), Postdoctoral Research Project of Qingdao (BY20170209) and the Sino-French International Laboratory (LIA) “Zeolites”.

\section{References}

[1] J.E. van den Reijen, S. Kanungo, T.A.J. Welling, M. Versluijs-Helder, T.A. Nijhuis, K.P. de Jong, P.E. de Jongh, J. Catal. 356 (2017) 65-74. 
[2] E. Okon, H. Shehu, E. Gobina, Catal. Today 310 (2018) 146-156.

[3] S. Gudyka, G. Grzybek, J. Gryboś, P. Indyka, B. Leszczyński, A. Kotarba, Z. Sojka, Appl. Catal. B 201 (2017) 339-347.

[4] P. Pardo, J. Alarcón, Ceram. Int. 44 (2018) 11486-11496.

[5] E. Rytter, A. Holmen, Catal. Today 275 (2016) 11-19.

[6] T.P. Mokoena, E.C. Linganiso, H.C. Swart, V. Kumar, O.M. Ntwaeaborwa, Ceram. Int. 43 (2017) $174-181$.

[7] X. Liang, X. Wang, Mater. Des. 112 (2016) 519-529.

[8] W.L. Suchanek, J. Am. Ceram. Soc. 93 (2010) 399-412.

[9] W.L. Suchanek, J.M. Garcés, P.F. Fulvio, M. Jaroniec, Chem. Mater. 22 (2010) 6564-6574.

[10] C. Wang, Y. Jia, Z. Zhang, G. Zhao, Y. Liu, Y. Lu, Appl. Surf. Sci. 478 (2019) 840-845.

[11] S.S. Punde, B.J. Tatarchuk, Appl. Catal. A 441-442 (2012) 54-64.

[12] J. Gascon, J.R. van Ommen, J.A. Moulijn, F. Kapteijn, Catal. Sci. Technol. 5 (2015) 807-817.

[13] A. Montebelli, C.G. Visconti, G. Groppi, E. Tronconi, C. Cristiani, C. Ferreira, S. Kohler, Catal. Sci. Technol. 4 (2014) 2846-2870.

[14] V. Paunovic, V. Ordomsky, M. Fernanda Neira D Angelo, J.C. Schouten, T.A. Nijhuis, J. Catal. 309 (2014) 325-332.

[15] S. Wahid, D.R. Cahela, B.J. Tatarchuk, AIChE J. 60 (2014) 3814-3823.

[16] A.V. Porsin, A.V. Kulikov, V.N. Rogozhnikov, A.N. Serkova, A.N. Salanov, K.I. Shefer, Catal. Today 273 (2016) 213-220.

[17] V. Novák, P. Kočí, T. Gregor, J. Choi, F. Štěpánek, M. Marek, Catal. Today 216 (2013) 142-149.

[18] J. Li, Y. He, L. Tan, P. Zhang, X. Peng, A. Oruganti, G. Yang, H. Abe, Y. Wang, N. Tsubaki, Nat. 
Catal. 1 (2018) 787-793.

[19] H. Yue, Y. Zhao, X. Ma, J. Gong, Chem. Soc. Rev. 41 (2012) 4218-4244.

[20] S. Peng, Z. Xu, Q. Chen, Z. Wang, D. Lv, J. Sun, Y. Chen, G. Guo, ACS Catal. 5 (2015) 4410-4417.

[21] X. Gao, Y. Zhao, S. Wang, Y. Yin, B. Wang, X. Ma, Chem. Eng. Sci. 66 (2011) 3513-3522.

[22] S. Peng, Z. Xu, Q. Chen, Y. Chen, J. Sun, Z. Wang, M. Wang, G. Guo, Chem. Commun. 49 (2013) $5718-5720$.

[23] C. Wang, L. Han, P. Chen, G. Zhao, Y. Liu, Y. Lu, J. Catal. 337 (2016) 145-156.

[24] C. Wang, L. Han, Q. Zhang, Y. Li, G. Zhao, Y. Liu, Y. Lu, Green Chem. 17 (2015) 3762-3765.

[25] C. Wang, W. Xu, Z. Qin, S. Mintova, Catal. Commun. 119 (2019) 39-41.

[26] M. Zhang, B. Xu, G. Ling, Appl. Surf. Sci. 331 (2015) 1-7.

[27] V. Maurice, G. Despert, S. Zanna, M.P. Bacos, P. Marcus, Nat. Mater. 3 (2004) 687-691.

[28] C. Kaplin, R. Ivanov, M. Paliwal, I. Jung, M. Brochu, Intermetallics 54 (2014) 209-217.

[29] K.R. Nemade, S.A. Waghuley, Ceram. Int. 40 (2014) 6109-6113.

[30] K. Laishram, R. Mann, N. Malhan, Ceram. Int. 38 (2012) 1703-1706.

[31] A.K.N. Kumar, S. Prasanna, B. Subramanian, S. Jayakumar, G.M. Rao, J. Appl. Phys. 117 (2015) $125307-125317$.

[32] J.A. Rotole, P.M.A. Sherwood, Surf. Sci. Spectra 5 (1998) 4-10.

[33] J.A. Rotole, P.M.A. Sherwood, Surf. Sci. Spectra 5 (1998) 53-59.

[34] J. Sung Lee, H. Soo Kim, J. Su Lee, N. Park, T. Jin Lee, M. Kang, Ceram. Int. 38 (2012) $6685-6691$.

[35] J.T. Kloprogge, L.V. Duong, B.J. Wood, R.L. Frost, J. Colloid Interface Sci. 296 (2006) 572-576. 
[36] Z. Shi, W. Jiao, L. Chen, P. Wu, Y. Wang, M. He, Microporous Mesoporous Mater. 224 (2016) $253-261$.

[37] X. Zhou, J. Ji, D. Wang, X. Duan, G. Qian, D. Chen, X. Zhou, Chem. Commun. 51 (2015) $8853-8856$.

[38] G. Busca, Catal. Today 226 (2014) 2-13.

[39] P. Chang, F. Yen, K. Cheng, H. Wen, Nano Lett. 1 (2001) 253-261.

[40] M.I.F. Macêdo, C.A. Bertran, C.C. Osawa, J. Mater. Sci. 42 (2007) 2830-2836.

[41] H.J. Grabke, Intermetallics 7 (1999) 1153-1158.

[42] Z. Li, W. Wang, D. Yin, J. Lv, X. Ma, Front. Chem. Sci. Eng. 6 (2012) 410-414.

[43] C. Wang, P. Chen, Y. Li, G. Zhao, Y. Liu, Y. Lu, J. Catal. 344 (2016) 173-183.

[44] M. Sheng, H. Yang, D.R. Cahela, B.J. Tatarchuk, J. Catal. 281 (2011) 254-262.

[45] Y. Li, Q. Zhang, R. Chai, G. Zhao, Y. Liu, Y. Lu, F. Cao, AIChE J. 61 (2015) 4323-4331. 